\title{
Os (des)abrigos do "eu" e as metáforas da casa na poesia de Alda Lara, Conceição Lima e Glória de Sant'Anna ${ }^{1}$
}

\author{
Érica Antunes Pereira ${ }^{2}$
}

RESUMO: Neste artigo, pretendemos analisar como as metáforas da casa contribuem para a formação da identidade nacional e/ou feminina na poesia de Alda Lara, Conceição Lima e Glória de Sant'Anna.

ABSTRACT: In this paper, we intend to analyze as the metaphors of the house contribute for the formation of the national and/or feminine identity in the poetry of Alda Lara, Conceição Lima and Glória de Sant'Anna.

PALAVRAS-CHAVE: Literaturas Africanas de Lingua Portuguesa; Poesia; Metáfora; Identidade.

KEYWORDS: African Literatures of Portuguese Language; Poetry; Metaphor; Identity.

\section{Buscando uma "afirmação de identidade"...}

Para além da idéia de espaço concreto, a imagem que o substantivo "casa” costuma suscitar tem natureza simbólica e está ligada à sensação de abrigo, refúgio ou tranqüilidade. $\mathrm{Na}$ poesia, essa conjetura ganha especial força à medida que a metáfora desempenha, na expressão de Northrop Frye (2000, p. 152), o papel de "afirmação de identidade", em que o sentido literal dos termos é subsumido pelas semelhanças ou pelas identificações entre eles estabelecidas. Nesse

\footnotetext{
1 Parte deste artigo foi apresentada oralmente no Colóquio "Caminhos da língua portuguesa: África-Brasil" realizado de 6 a 9 de novembro de 2006 na Universidade Estadual de Campinas (UNICAMP).

2 Doutoranda em Estudos Comparados de Literaturas de Língua Portuguesa na Universidade de São Paulo (USP) e bolsista da Fundação de Amparo à Pesquisa do Estado de São Paulo (FAPESP). Pesquisa: Da catana ao batom: Diferentes perspectivas da representação do feminino na poesia africana de língua portuguesa - análise das obras de Alda Espírito Santo, Alda Lara, Conceição Lima, Glória de Sant'Anna, Noémia de Sousa e Paula Tavares. E-mail: erica.antunes@gmail.com.
} 
caso, quando dizemos, por exemplo, que "O campo é o ninho do poeta", podemos encarar a metáfora tanto como uma forma poética de expressão - e então as palavras "campo" e "ninho" têm pesos idênticos - quanto, mais profundamente, como o meio revelador de um intrínseco vínculo simbólico entre os dois espaços - aqui, pela dimensão de um e de outro, o "ninho" assume uma roupagem protetora e aconchegante que não costuma caracterizar o "campo" e que, em última análise, implica afirmar que "campo" e "ninho" se identificam, mas não se equivalem.

A relação entre a identidade e a metáfora, portanto, revela-se bastante estreita: se aquela se caracteriza pela definição do "ser", esta diz respeito ao "como" o "ser" é representado. Assim, considerando que o sujeito - o "eu" - constitui figura essencial quando tratamos da questão da identidade, já que é ele quem indaga ou faz indagar acerca do fato de estar/ser/pertencer no/do/ao mundo, precisamos, o quanto antes, "conhecer quem pergunta pela identidade, em que condições, contra quem, com que propósitos e com que resultados" (SANTOS, 2003, p. 135). Muitas vezes, o desvendamento de tais questões ocorre a partir da análise das metáforas contidas no texto, de modo a privilegiar o vínculo entre o sujeito e a representação do mesmo. No caso do exemplo de que nos valemos há pouco, o "ninho" se contrapõe à extensão do "campo" e, paradoxal e concomitantemente, dele se aproxima, configurando a imagem do "poeta" como um sujeito em equilíbrio.

No entanto, tal qual a identidade, as metáforas não são estáticas, podem variar conforme o contexto e tomar sentidos muito diversos daqueles concebidos numa primeira leitura: o "ninho", pois, se assim o determinar o universo diegético, pode não mais se ligar à noção de abrigo, refúgio ou tranqüilidade e adquirir novas direções. Para demonstrar como se dão essas transformações, passamos agora a analisar a relação dos sujeitos poéticos com as metáforas da casa em 
alguns poemas da angolana Alda Lara, da são-tomense Conceição Lima e da moçambicana Glória de Sant'Anna³.

\section{A casa como espaço do abrigo e do desabrigo}

Ao pensarmos a "casa" como índice de abrigo, refúgio ou tranqüilidade, lembramo-nos, imediatamente, de Davi Arrigucci Jr., que, ao analisar o "Poema só para Jaime Ovalle", de Manuel Bandeira, descreve o quarto habitado pelo poeta - tomado, por analogia, como a casa deste - como "o espaço do recolhimento", caracterizado por ser "onde a vida se aconchega, aninhando-se no mais intimo, mas onde se entrega também ao mundo de fora, resgatando-o interiormente; onde se processa o movimento que enlaça o sujeito e o objeto; onde, enfim, o vivido se muda por palavras em poesia” (ARRIGUCCI JR., 2003, p. 64). Essa relação do espaço exterior com o interior também aparece no poema "Vida que se perdeu", de Alda Lara (1984, p. 61-62), em que o sujeito poético se encontra "Na minha [sua] mesa de estudo", "Na minha [sua] mesa de trabalho" - portanto, preso a um aposento - e envolvido com seus afazeres.

Mas as semelhanças entre os poemas terminam aí; se o quarto de Bandeira é "arejado, onde o mundo penetra enquanto dimensão social e enquanto natureza” (ARRIGUCCI JR., 2003, p. 64), o mesmo não pode ser dito a respeito do cômodo descrito no poema de Alda Lara: neste, a "janela [está] fechada" e para além dela é que "Está a VIDA!...". A palavra "VIDA", escrita com letras maiúsculas na segunda e terceira

\footnotetext{
${ }^{3}$ Pelo fato de Glória de Sant'Anna ter nascido em Portugal e por sua poesia ser considerada de cunho universal ou existencial, Russel G. Hamilton denomina-lhe "euromoçambicana" (cf. HAMILTON, Russel G. Literatura africana, literatura necessária, II - Moçambique, Cabo Verde, Guiné-Bissau, São Tomé e Príncipe. Lisboa: Edições 70, 1984, p. 63 e 87). Desde já, registramos a nossa discordância quanto a tal posicionamento, situando-nos ao lado de Carmen Lucia Tindó Secco que, a respeito, afirma: "Consideramos esse critério bastante discutivel, pois apenas leva em consideração a pátria de nascimento da autora, ignorando os pactos afetivos de identificação tecidos durante sua longa vivência em terras africanas" (cf. SECCO, Carmen Lucia Tindó. Uma poética de mar e silêncio... In: A magia das letras africanas: ensaios escolhidos sobre as literaturas de Angola, Moçambique e alguns outros diálogos. Rio de Janeiro: ABE Graph: Barroso Produções Editoriais, 2003, p. 158).
} 
estrofes, acentua o grau de insatisfação do sujeito poético que, além de fisicamente enclausurado, enfrenta o agravamento de sua saúde psicológica à medida que passa todo o tempo - e agora começamos a perceber a relação tempo versus espaço embutida no poema - diante da mesa, entre as "pobres concepções doentes" e a "tristeza" emersa de seu interior. A janela fechada, portanto, representa o limite entre dois espaços diametralmente opostos; observemos, também, que o sujeito poético enxerga a "VIDA" através do vidro da janela, embora, ao contrário do que ocorria com Manuel Bandeira, isso não implique seu resgate interior: de qualquer modo, tal fato acena para uma força interna do sujeito poético que, apesar de estar com a "cabeça curvada/ Sôbre o palavriado/ Complexo/ E sem nexo,/ Que os livros contêm!...”, pode, a qualquer momento, insurgir-se contra a postura por si adotada e, por assim dizer, saltar a janela e sentir sobre a pele o "sol esplendoroso de Verão,/ Um vestido de algodão" ou partilhar o "riso duma criança/ Que esvoaça/ E grita Esperança!...”.

As rimas, ainda que pobres (trabalho/retalho; mesa/tristeza; Verão/ algodão; criança/Esperança; fechada/curvada; complexo/nexo; Espaço/cansaço), o recorrente emprego das reticências e os interregnos entre várias das estrofes ( $1^{\mathrm{a}}$ e $2^{\mathrm{a}}, 3^{\mathrm{a}}$ e $4^{\mathrm{a}}, 5^{\mathrm{a}}$ e $6^{\mathrm{a}}$ e após a $6^{\mathrm{a}}$ ) demonstram que o sujeito poético se apanha em incansável reflexão. Tanto essa idéia tem fundamento que todo o poema é construído no presente do indicativo, à exceção da quinta estrofe que, ao surgir isolada no pretérito perfeito, torna irreversível a inércia do sujeito poético diante dos fatos: "Ah! Vida que eu apeteci/ Estreitar nos braços,/ De encontro ao peito,/ E que perdi.../ Ah! Vida que eu não vivi!...” As duas interjeições contidas nessa mesma estrofe reforçam o tom lamentoso do sujeito poético que, definitivamente, não consegue abrir a janela para viver a "VIDA" que sabe existir do lado de fora, daí também o título do poema ser "Vida que se perdeu". Mais, os versos "Estreitar nos braços,/ De encontro ao peito," além de ilustrarem a relação que o sujeito poético desejaria estabelecer com a "Vida", lembram o vínculo da mãe com o seu bebê e trazem à tona as sensações 
de aconchego e proteção: assim, o corpo do sujeito poético, ao se aproximar da figura materna, pode também ser visto como uma metáfora da casa.

Neste poema de Alda Lara, observamos, então, a presença de dois espaços internos - um representado pelo aposento e outro pelo corpo - em confronto com um terceiro espaço, agora externo, simbolizado pelas imagens do "sol esplendoroso de Verão", do "vestido de algodão" e do "riso duma criança", fortes o bastante para que o sujeito poético resuma nelas a "VIDA!..." sempre exclamativa e reticente. A janela fechada, mas de vidro, remete-nos à simbologia do olho, costumeiramente tido como "a janela da alma"; assim, conforme a atitude do sujeito poético se mostre mais contemplativa e menos dada à ação, mantendo a janela sempre fechada, instaura uma noção de inércia que, para além do sono, conduz à sua morte interior e reforça o título do poema.

Finalmente, a sexta e última estrofe - "No Espaço/ Paira o meu [do sujeito poético] cansaço!..." - margeada por linhas pontilhadas que parecem materializar os hiatos da vida, torna nítida a afirmação de que, em "Vida que se perdeu", a metáfora da casa se exaure nos desabrigos interiores - o do aposento e o do corpo - pelo sujeito poético experimentados.

\section{O paraíso revisitado}

No esteio das relações entre abrigo e desabrigo, exterior e interior, o sujeito poético do poema “A casa”, de Glória de Sant'Anna (2005, p. 22-23) apresenta um ambiente oposto ao aposento divisado em "Vida que se perdeu". Os cinco versos iniciais, "risos rompem a madrugada/ que surge cor de rosa// passos leves palmilham/ o corredor// os chuveiros tilintam", só para exemplificar, são tomados por signos positivos, benéficos, indutores de um dia agradável. Esse clima de leveza introduzido verso a verso atinge um tom paradisíaco com os pombos que atendem ao chamado do sujeito poético, as "casuarinas 
lentas/ a que brisas", "as buganvilias rubras e as rosadas/ [que] abraçam as petúnias", além dos "colibris pairando nos hibiscos", das "amoreiras e atas e papaias/ e mangas", das "flores de santo antónio" e das "amêndoas da Índia".

A memória de um tempo idílico instaura a permanência a partir do redivivo cultivo do cotidiano e pode ser percebida com base nos verbos conjugados no presente do indicativo em todo o poema; além disso, o verso "(mangas verdes com sal)", ao ser disposto entre parênteses, alude a momentos bastante apraziveis, recuperadores da infância. Nesse sentido, ao poema de Glória de Sant'Anna pode ser aplicada a análise que Manoel de Souza Silva (1996, p. 105) faz do poema "Mangas verdes com sal", de Rui Knopfli", ao afirmar que "a superação da ambivalência ${ }^{5}$ não dispensa, sequer, a visitação das cores, cheiros e sabores da infância, fundidos na memória, numa espécie de tentativa de recuperação de si mesmo num estágio menos propenso às racionalizações".

A recuperação da infância e, portanto, do paraíso é ainda reiterada pela estrofe "tudo murmura/ e os muros/ abertos a quem passa/ não têm portas", pois "tudo [aquilo que] murmura" é vivo, freme, pulsa; mais, ainda que essa casa-jardim semelhe uma campânula, a penetração em tal universo é permitida a todos: tanto os muros são abertos quanto inexistem portas.

De outra feita, mesmo esse universo edênico não se eterniza: a conjunção coordenativa adversativa "mas", presente no verso "mas agora (ai) agora", introduz o "agora", instante-já, fase antes não experimentada porque os dias se sucediam com toda a calma. Essa

\footnotetext{
${ }^{4}$ Eis o poema "Mangas verdes com sal" de Rui Knopfli: "Sabor longínquo, sabor acre/ da infância a canivete repartida/ no largo semicírculo da amizade.// Sabor lento, alegria reconstituída/ no instante desprevenido, na maré-baixa,/ no minuto da suprema humilhação.// Sabor insinuante que retorna devagar/ ao palato amargo, à boca ardida,/ à crista do tempo, ao meio da vida." (KNOPFLI, Rui. Mangas verdes com sal. In: FERREIRA, Manuel. No reino de Caliban III: antologia panorâmica de poesia africana de expressão portuguesa - Moçambique. Lisboa: Plátano, 1985, p. 284).

5 O autor utiliza a palavra "ambivalência" para se referir àqueles "casos que não contam com a aprovação unânime - pelo menos enquanto se trata de sua aprovação como poetas moçambicanos" (1996, p. 103), o que também ocorre com Glória de Sant'Anna.
} 
mudança de perspectiva é reforçada pela subjetividade do “(ai)” entremeado de "agoras" e abre passagem para a angústia. Assim, a partir de "agora", "a minha [do sujeito poético] casa está fechada/ por agudas e altas paliçadas/ erguidas como espadas/ que escondem a ternura/ das flores das seivas dos abraços”. Tal estrofe pode abarcar duas possíveis leituras quanto ao quesito espacial: a primeira é a de que a casa continue a ser a inscrição do éden, embora ele agora esteja fechado, restrito a poucos, exclusivamente aos que forem autorizados a ultrapassar as "agudas e altas paliçadas" que, como "espadas", prestam-se à defesa e instauram o maniqueísmo para aquém e para além dos limites dos muros; a segunda, a de que a casa não seja mais o espaço externo, mas, ao revés, a própria subjetividade do sujeito poético que se fecha em copas, tornando-o inatingivel graças a um absoluto recolhimento interior.

Resta estabelecida, a partir dessa segunda leitura, a relação casacorpo de que fala Mircea Eliade (2001, p. 144): "Habita-se um corpo da mesma maneira que se habita uma casa ou o Cosmos que se criou para si mesmo". Precisamos estar atentos, porém, para o fato de que, diversamente do poema "Vida que se perdeu", de Alda Lara, o sujeito poético que habita "A casa”, de Glória de Sant'Anna, não está desabrigado; muito pelo contrário, tão resguardado se encontra que toda "a ternura/ das flores das seivas dos abraços" desaparece entre as “agudas e altas paliçadas”.

Mas não é só: toda essa transformação — quer vista pelo prisma do espaço externo, quer pelo do interno - entristece o sujeito poético a tal ponto que justo sobre "a ternura/ das flores das seivas dos abraços" é que “tombam silentes/ estas lágrimas// sobre o chão de mosaico”. O silêncio, na poética de Glória de Sant'Anna, é, conforme Carmen Lucia Tindó Secco (2003, p. 164), "tramado pela densidade de emoções e sentimentos despertados por situações várias: de beleza, de ternura, de ódio, de dor, de medo, de angústia, de saudade”. Se pensarmos no significado da palavra "mosaico", podemos afirmar que as lágrimas que "tombam silentes" revelam, simbolicamente, tanto a fragmentação 
interna vivenciada pelo sujeito poético quanto a sua fortaleza exterior: dois mundos que se comunicam pela metáfora da casa.

\section{Um projeto de (re)construção}

Tom menos melancólico e mais incisivo tem o poema de Conceição Lima, cujo título é, também, "A casa" (2004, p. 19); nele, observamos ser recorrente o emprego de verbos de ação e de substantivos concretos e, à medida que se opera a passagem do pretérito perfeito - indicativo de algo efetivamente realizado - para o presente, há o levantar de um projeto que, mesmo ainda não concluído, continua a ser acalentado.

Ao iniciar o primeiro verso - "Aqui projectei a minha casa:" com um advérbio de lugar, o sujeito poético, de plano, circunscreve o seu espaço de atividade: "aqui” não é um lugar qualquer, está delimitado, escolhido. Do mesmo modo, trata-se de uma "casa" única, afirmação que abstraímos do uso do artigo "a" e do pronome possessivo "minha" em anteposição ao substantivo. Além disso, a casa projetada possui características que a tornam ainda mais singular: é "alta, perpétua, de pedra e claridade”, adjetivos positivos que, conotativa e respectivamente, apontam para a verticalidade, a perenidade e a tranqüilidade ou a lucidez. A distinção se dá, ainda, pelo "basalto negro, poroso/ [que] viria da Mesquita" e pelo "barro vermelho/ da cor dos ibiscos/ para o telhado" oriundo do Riboque, características que, além de função utilitária, valem como ornamento. É importante, nesse ponto, atentarmos para o fato de Mesquita e Riboque serem duas cidades vizinhas e próximas a São Tomé, a capital de São Tomé e Príncipe, pois, conforme afirma Inocência Mata (2004, p. 12) na apresentação da obra O útero da casa - título para nós bastante sugestivo - , este é dos poemas "que, situando-se num plano reflexivo, controem o relato de uma geração, metonímia de um segmento narrativo do relato da nação".

A idéia da casa-nação toma consistência do oitavo ao décimo quarto verso, caso em que podemos ler: a) a "Enorme janela e de vidro" 
como a representação do céu, da soberania e da transparência política ou econômica ou de outra ordem em São Tomé e Príncipe; b) "a sala [que] exigia um certo ar de praça” como a capital, São Tomé, uma vez que a sala costuma ser considerada o principal compartimento da casa; c) "O quintal [que] era plano, redondo/ sem trancas nos caminhos" simbolizando todo o território são-tomense; e, d) a projeção da casa "Sobre os escombros da cidade morta" e "recortada contra o mar" como um indício do desejo de reconstrução do país manifestado após a independência. Observamos, ainda, que neste poema, a exemplo de "A casa”, de Glória de Sant'Anna, analisado anteriormente, uma extensão sem obstáculos é ansiada, ideal, porque acessivel a todos.

Novamente, o advérbio de lugar — "Aqui." - aparece, mas desta vez constituindo sozinho um verso, numa reiteração da certeza manifestada pelo sujeito poético acerca do espaço; é aquele e nenhum outro o seu lugar, o seu país, a sua casa. O projeto da casa, porém, conforme já adiantamos alhures, não está concluído; é o que canta o sujeito poético nos versos "Sonho ainda o pilar -/ uma rectidão de torre, de altar". Como sabemos, o pilar, simbolicamente, significa a relação do "eu" com o universo, uma espécie de sustentáculo do céu, idéia que se torna viável quando pensamos, com Mircea Eliade, que o ato de "instalar-se num território, construir uma morada pede (...) uma decisão vital, tanto para a comunidade como para o indivíduo”, pois "trata-se de assumir a criação do 'mundo' que se escolheu habitar" (ELIADE, 2001, p. 49).

O importante, nesse poema de Conceição Lima, é percebermos que o sujeito poético não se esquiva do intento de (re)construir a casa em momento algum; tanto isso é ajustado que o fato de ouvir "murmúrios de barcos/ na varanda azul" - quer pela vivificação promovida pelos "murmúrios", quer pela liberdade de trânsito característica dos barcos ou, talvez, sobretudo pelo fato de a varanda ser azul, cor simbolicamente ligada à transformação do real em imaginário - faz com que ele, tal qual as gregas Parcas tecedoras do destino dos homens, reinvente "em cada rosto fio/ a fio/ as linhas 
inacabadas do projecto", numa renovação esperançosa de, um dia, levar a cabo a (re)construção da casa, da nação e, por conseqüência, de si mesmo.

\section{Uma fênix renascida das cinzas}

Seguindo também uma linha que podemos chamar de social, o "Poema para um dia de chuva", de Glória de Sant'Anna (2000, p. 60), apresenta um sujeito poético que parece empenhado em (re)construir as relações humanas. No verso inicial - "A minha casa é um farol no meio da noite" - , percebemos que conforme a luminosidade do farol se opõe à escuridão noturna, a segurança experimentada pelo sujeito poético adquire força incontestável e o capacita para, imperativamente, sem nenhum medo, chamar: "Vem, seja quem fores". A casa, aqui, como vimos há pouco no poema de Conceição Lima, pode simbolizar a nação ou, mais especificamente, o país: feito a fênix, ele renasce das cinzas da guerra, da noite - graças à solidariedade e à coragem de seu povo.

$\mathrm{O}$ fato de o sujeito poético chamar para o interior da casa pessoas indistintas - "sejas quem fores" - demonstra ainda o seu desprendimento de questões raciais, sociais ou etnológicas, por exemplo, adiantando o sentimento vindouro de seu interlocutor: "ficarás a princípio como a haste de uma flor/ gotejando sobre o tapete// e nós olhar-te-emos/ da cor da chuva”, ou seja, recebido num espaço que antes não lhe cabia, o estrangeiro se torna suscetível, fragilizado, alvo de curiosidade posto que exótico. O tapete é, simbolicamente, o solo da nação; a casa, a própria nação em sua integridade. Aqui, é inevitável entrevermos a relação entre colonizador e colonizado, mas com papéis trocados: aquele que chega - "sejas quem fores" - não é, na concepção do poema, o colonizador; a figura deste é exercida pelo sujeito poético que, destemidamente, convida o estrangeiro para habitar a casa e tem consciência da fragilidade do outro.

No entanto, essa analogia se desfaz "imediatamente, quase imediatamente", tão logo o sujeito poético conforta seu interlocutor: 
"sentirás nas tuas as palmas quentes/ das nossas mãos// e acharás no desenho dos nossos risos/ a tradução da hora”. Não há, portanto, os embates entre colonizador e colonizado tão bem delineados por Albert Memmi (1989); neste poema, há, isto sim, unicamente pessoas. Em outras palavras, a idéia do desabrigo advinda do título "Poema para um dia de chuva" é distanciada porque no fluir dos versos há a celebração do acolhimento.

Não podemos, ainda, deixar de anotar que embora possua uma enorme carga existencial, este poema - como muitos outros - de Glória de Sant'Anna não deixa "de problematizar as questões sociais" (SECCO, 2003, p. 161); tanto isso tem substância que a casa metaforiza a nação (re)construída a partir da força conjunta, da solidariedade. Nesse sentido - e para finalizar —, são pertinentes as palavras de Theodor W. Adorno (2003, p. 74), para quem

a lírica se mostra mais profundamente assegurada, em termos sociais, ali onde não fala conforme o gosto da sociedade, ali onde não comunica nada, mas sim onde o sujeito, alcançando a expressão feliz, chega a uma sintonia com a própria linguagem, seguindo o caminho que ela mesma gostaria de seguir.

\section{Uma solidariedade solitária}

A solidariedade também aparece com muita força no poema "Para leres numa manhã de chuva”, de Alda Lara (1984, p. 119), ainda que só tenhamos condições de confirmá-la nos dois últimos versos. A construção sintática é relativamente simples, com fartura de verbos no presente do indicativo, de substantivos concretos e de adjetivos de carga simbólica negativa, sem falar no advérbio "quando" que, iniciando três versos, remete-nos à relação tempo versus espaço. A respeito da recorrência, Alfredo Bosi (2000, p. 41) afirma que "re-iterar um som, um prefixo, uma função sintática, uma frase inteira significa realizar uma operação dupla e ondeante: progressivo-regressiva, regressivoprogressiva". 
Neste poema, o sujeito poético é expresso pela primeira pessoa do plural - nós - e acena para a idéia de compartilhamento. Entretanto, na primeira estrofe, "a chuva [que] cai" "de um céu pesado/ de amargura e acusação..." é "impiedosa e rija", "dolorosa e triste" e encharca "de lágrimas/ os telhados das casas todas...", gerando o desejo de afastamento e instaurando a solidão no/do sujeito poético. A segunda estrofe confirma o hermetismo prenunciado à medida que "agonias esquecidas/ nos sobem outra vez no peito.../ (ah! essa sensação de nada se ter feito!...)”, bem como “...a lembrança das horas inúteis,/ dos anseios desprezados,/ dos gestos impiedosamente deturpados...”.

As reticências, as rimas (dolorosa/ impiedosa; peito/feito; desprezados/ deturpados), a interjeição e a reiteração - também divisadas em "Vida que se perdeu", sinalizando alguns traços recorrentes na poética de Alda Lara - dão passagem para a reflexão e o lamento; assim, a despeito de o sujeito poético se anunciar em comunhão com outros sujeitos, o "nós" camufla o cavar da solidão interior. Em verdade, o sujeito poético habita uma casa-corpo tão impermeável que beira o autismo, numa imagem que contradiz o título do poema, naturalmente molhado. No entanto, essa secura interior é abrandada aos poucos - o título, mais uma vez, é significativo, sendo "manhã", há todo um dia pela frente -, conforme o sujeito poético experimenta - e para isso colabora o advérbio temporal "quando" que dá início a três versos - um parentesco entre si e a natureza. Contudo, somente após um processo de depuração interna em que aflora "toda a agonia de uma vida mesquinha" é que passa a existir uma identidade plena: o fato de o sujeito poético e a natureza chorarem/choverem juntos torna dois espaços - o espaço da intimidade e o espaço do mundo, a casa-corpo e a casa-cosmo - consoantes, pois, como afirma Gaston Bachelard (2005, p. 207), "quando a grande solidão do homem se aprofunda, as duas imensidões se tocam, se confundem". Trata-se de uma solidariedade solitária, sem dúvida. Mas solidária. 


\section{No centro do anel}

Também no poema “São João da Vargem”, de Conceição Lima (2006, p. 57-66), organizado em quatro partes distintas denominadas, respectivamente, como "O anel das folhas, "A sombra do quintal", "As vozes" e "Os olhos dos retratos", o sujeito poético manifesta preocupação com a busca da própria identidade. Embora essas partes possam ser lidas como poemas autônomos, em conjunto elas corroboram para a constituição da completude pessoal almejada pelo sujeito poético ao refazer o percurso dos espaços que habitou na infância. Tal afirmação ganha notoriedade se pensarmos que cada uma dessas divisões é iniciada pelo advérbio de lugar "quando" - eis-nos, novamente, à mercê da relação tempo versus espaço - e pela autoanálise do sujeito poético que, ao empregar os verbos no pretérito imperfeito para tentar se definir em tais épocas, faz-nos acreditar que, no presente, os dramas identitários tenham sido sanados. É mesmo com esse sentido que Alfredo Bosi (2000, p. 42) trata da reiteração:

Entre a primeira e a segunda aparição do signo correu o tempo. O tempo que faz crescer a árvore, rebentar o botão, dourar o fruto. A volta não reconhece, apenas, o aspecto das coisas que voltam: abre-nos, também, o caminho para sentir o seu ser. A palavra que retorna pode dar à imagem evocada a aura do mito. A volta é um passo adiante na ordem da conotação, logo na ordem do valor.

Analisando a primeira porção, intitulada "O anel de folhas", percebemos um sujeito poético mergulhado na infância pregressa: “Quando eu não era eu/ Quando eu não sabia que já era eu/ Quando não sabia que era quem sou/ os dias eram longos e redondos e cercados/ e as noites profundas como almofadas”. A memória afetiva ligada aos dias e às noites se manifesta a partir de imagens que lembram intensidade, circularidade, proteção e aconchego: é uma criança feliz, que vive num "mundo [que] era grande e [que] era fechado como um anel”, mas que, ainda assim, podia sobrepujar, pois "eu [o sujeito poético] era grande, eu [o sujeito poético] tinha o mundo, eu [o 
sujeito poético] tinha o anel”. Nessa senda, como diz Gaston Bachelard (2005, p. 35), "para além de todos os valores positivos de proteção, na casa natal se estabelecem valores de sonho", de modo que o sujeito poético, valendo-se de um sonho-lembrança, recria a casa onde "Viviam plantas, viviam troncos, viviam sapos/ Vivia a escada, vivia a mesa, a voz dos pratos" - imagens que podemos facilmente reconstituir a partir de nossas próprias infâncias —, mas não só: havia também "um untueiro", "fruteiras", "limoeiros", "makêkês, berigelas, pega-latos/ verdes kimis”, “swá-swás”, “o ido-ido", "morcegos”, "Folhas da mina", "fios d'orvalho", "libo d'água/ pinincanos, folha-ponto e salakontas", "fyá xalela" e "O micondó", e muitos outros elementos da flora e da fauna são-tomense.

Embora fosse interessante analisarmos cada um deles, vamos nos ater apenas ao "micondó" por constar no título da obra que alberga o poema, A dolorosa raiz do micondó. Em "São João da Vargem”, o sujeito poético o define como "a força parada e recuada/ [que] escutava segredos, era soturno, era a fronteira/ e tinha frutos que baloiçavam, baloiçavam/ nunca paravam de baloiçar”, o que nos transporta para a simbologia da "Árvore do Mundo" que, segundo Mircea Eliade, representa a ligação da "Terra ao Céu” (2001, p. 51); por isso é que o sujeito poético qualifica o micondó como "a fronteira". E já que a idéia de “Árvore do Mundo" parece muito eficaz, o "anel das folhas”, farta e minuciosamente descrito, deve estar relacionado com a imagem do paraíso por nós já vista quando da análise do poema "A casa”, de Glória de Sant'Anna, aqui reforçada pelos versos "Não havia horas, ninguém tinha pressa/ senão minha [do sujeito poético] mãe”.

A segunda parte, denominada “A sombra do quintal”, também é iniciada com as reflexões auto-analíticas do sujeito poético - "Quando eu não sabia que era quem sou/ Quando eu ainda não sabia que já era eu" - e, da mesma forma que na anterior, lista uma série de lembranças que o remetem à infância. A diferença é que, agora, tais referências, em sua maioria, não são alusivas à fauna ou à flora sãotomense, mas aos seus habitantes: o "Dadá”, o "Minho", o "Buggy", o 
"Valdemar", "a Aninha e o Zé", "Napoleão" e "avó Nôvi”, infantilmente descrita como a que "Trazia pestanas que se mexiam como asas severas/ Trazia saquinhos, bananas-maçã em cachos de ouro/ Trazia consigo a voz que apagava o ruído das coisas". Aqui, o sujeito poético não fala mais no anel, mas ainda se entende como o dono do mundo e do quintal, mesmo já tendo a noção de que "o mundo era [é] grande".

A porção seguinte, “As vozes”, continua absorvida na memória das gentes que habitaram a infância do sujeito poético; no entanto, as reflexões acerca de sua presença no mundo se tornam nitidamente amadurecidas. Assim é que a atenção é voltada para "os olhos da tia Espírito/ abertos buscando o caminho da luz", para "as velhas primas Venida e Lochina/ com ecos de ontem na palma das mãos", para "a tia san Límpia que nunca sabia do paradeiro/ do seu Nicolau" e para a vida das peixeiras "Vingá", "Malanzo, Adelina e Nólia”. Nessa paragem, o sujeito poético já não possui mais o mundo - o mundo se torna "plano" -, mas ainda lhe resta o quintal. Acerca das representações deste, invocamos Alfredo Margarido (1980, p. 397) que, apesar de se referir ao quintal vislumbrado em $O$ segredo da morta, de Assis Júnior, não nos impede de tomar como válidas as suas palavras também para este poema de Conceição Lima:

Quer dizer que os africanos ${ }^{6}$ se encontram encerrados num espaço fechado, o quintal, que é todavia uma parte da natureza, pois não existe nenhuma cobertura, associando este grupo aos valores naturais. O que também quer dizer que estes homens são pensados como "naturais" ou seja "não civilizados". O quintal é assim vizinho da civilização, mas não ainda civilização. O que já não acontece com a burguesia, cujas casas repetem o modelo europeu, que separa o homem da natureza, e se lhe opõe.

Guando o sujeito poético afirma que ainda tem o quintal, deve, com base nessas idéias de Alfredo Margarido, estar em busca da própria identidade, ato materializado pela preservação tanto dos ditos "valores

\footnotetext{
${ }^{6}$ Leiamos, aqui, são-tomenses.
} 
naturais”, quanto dos laços familiares. O quintal, portanto, reitera a noção do paraíso.

Por sua vez, a quarta e última parte que compõe o poema, denominada "Os olhos do retrato", retoma os percursos do sujeito poético rumo ao (re)conhecimento de si - "Quando eu não sabia que era eu/ Quando eu sentia que o mundo era meu/ Quando eu não sabia o mundo que era eu" - e, finalmente, compreende o ciclo da vida. Volta-se, então, para a análise dos retratos que, tanto quanto os vivos, habitam a casa: chamam-lhe a atenção os "estranhos bigodes", os "casacos de pontas compridas/ estranhos casacos, que faziam rir", as "saias compridas e [as] longas mantilhas" das mulheres, "A velha prima Olímpia Barros que era tão velha/ [e que] tinha uma mãe bem mais nova que ela" demonstrando a dificuldade infantil de entender o tempo e "o tio Palácio" que "tentara um dia disparar sobre o avô", algumas imagens e muitas histórias ocultas para sempre por conta da fatalidade da morte. O sujeito poético, como vemos, procura resgatar uma identidade perdida a partir da observação e da querença guardada pelo seu lugar e pela sua gente. E cremos que consegue, pois, encerrando o ciclo, ele canta que "dormia em paz, a casa era limpa no centro do anel”, ou seja, mesmo nada possuindo materialmente falando, restou ao sujeito poético a paz de permanecer em casa.

\section{O ciclo da borboleta}

Outro poema que focaliza a infância para questionar a identidade é "Estrelas mortas", de Alda Lara (1984, p. 80); desde o título, notamos a oposição entre os termos: apesar de serem "estrelas”, o fato de estarem mortas as destitui de toda luminosidade. Logo, mais uma vez entrevemos a relação tempo versus espaço, já que "A menina cresceu..." e "Nunca mais usou laços no cabelo,/ nem chapéus com fitas largas / a esvoaçar ao vento.../ Nunca mais pôs bibes de riscado aos quadradinhos.../ ... E as borboletas,/ perderam-se, esquecidas nos caminhos..." Essa primeira estrofe nos lembra Fita Verde no Cabelo: 
nova velha estória, de Guimarães Rosa (2004), obra que analisamos há algum tempo e cujas imagens guardam bastante intimidade com as do poema de Alda Lara, pois como afirmamos lá e reafirmamos agora, elas - as borboletas - representam "o desabrochar para a vida, ou, ainda, a adolescência, momento em que o indivíduo começa a enxergar o todo, tomando-se de dores e epifanias aliadas à curiosidade de se sentir humano e participante do mundo" (ANTUNES, 2002).

No entanto, se em Fita Verde no Cabelo as borboletas ainda existiam, mas "nunca em buquê nem em botão" (ROSA, 2004), em "Estrelas mortas" elas "perderam-se, esquecidas nos caminhos...". Com suas metamorfoses, as borboletas se ligam, simbolicamente, ao processo de crescimento do ser humano; assim, conforme restam, no poema, "esquecidas nos caminhos", nítida se torna a referência à velhice. Tanto assim que, nas estrofes seguintes, "o quarto de brinquedos" aparece fechado "para sempre" e "Na boca da menina,/ o tempo cavou um sorriso,/ sempre igual... e sempre triste.../ $\mathrm{E}$ as suas mãos, agora longas,/ de unhas sangrentas,/ nunca mais quiseram agarrar a lua,/ nas noites belas.../ ... nunca mais...”. Reunidos, esses emblemas remetem aos ciclos sazonais, sobre os quais escreve Benjamin Abdala Junior (2003, p. 230-231):

Os simbolos terrestres têm ciclos sazonais regulados pelos anos solares. As interferências nesses ciclos vêm do ritmo lunar, que se fazem sentir numa periodicidade mais curta e em atmosfera noturna. São essas interferências, não obstante, as mais fortes para a imaginação popular pela maior evidência, sobretudo nos trópicos, das fases da lua. O ritmo lunar liga-se, é evidente, à situação da mulher em suas matizações sexuais.

A partir do momento em que "as noites fizeram-se mais escuras,/ e menos belas.../ Noites de bruma,/ onde as estrelas se apagaram todas, / uma por uma...", a capacidade gerativa feminina se esgota e o processo de envelhecimento é completado. Assim, o sujeito poético se vê desabrigado desse corpo-casa que sempre habitou; mas, além do corpocasa, há seu desal(ojam)ento da casa-cosmo, uma vez que, sobre si, 
agora, pairam apenas as "Estrelas mortas" e "as noites [que] fizeram-se mais escuras". "E tudo, porque a menina cresceu..."

\section{A força matriz da nação}

Encerrando a simbologia da maternidade desde o título, o poema "Mátria”, de Conceição Lima (p. 2004, p. 17-18), apresenta, na análise de Inocência Mata (2004, p. 12), "um sentido protector, de um lugar matricial em que assenta a busca da utopia e do sonho" de "nível colectivo". A analogia dos vocábulos "mátria” e "pátria”, neste poema, traz à tona a metáfora da casa-nação, reiterada conforme se dá a sucessão dos versos. Logo nos primeiros, quando sujeito poético afirma que se quer "desperta/ se ao útero da casa retorno [retorna]" para, com lucidez, "tactear a diurna penumbra/ das paredes/ na pele dos dedos reviver a maciez/ dos dias subterrâneos/ os momentos idos”, manifesta o desejo de, simbolicamente, renascer e, palmo a palmo - como observamos também em outro poema da autora, "A casa" (re)construir-se e à nação.

Obviamente que essa gana pelo refazimento só é possivel porque o sujeito poético crê "nesta amplidão/ de praia talvez ou de deserto", bem como "na insónia que verga/ este teatro de sombras", ou seja, acredita tanto no solo que corporifica a nação quanto na gente que luta para torná-la melhor. Na terceira estrofe, o sujeito poético se dirige a um interlocutor que parece mergulhado no desespero - um "riacho de dor cascata de fúria/ pois a chuva demora e o obô entristece/ ao meio-dia" - e a ele, com toda convicção, afirma: "Não lastimo a morte dos imbondeiros/ a Praça viúva de chilreios e risonhos dedos”, fato verificado porque o sujeito poético pressente que não há mais que uma questão de tempo para que da "insónia que verga/ este teatro de sombras" surja o projeto para a (re)construção da casa.

$\mathrm{Na}$ estrofe final, o sujeito poético descreve o seu país - as ilhas de São Tomé e Príncipe - como "Um degrau de basalto [que] emerge do mar" e arremata: "na dança das trepadeiras reabito/ o teu corpo/ 
templo mátrio/ meu castelo melancólico/ de tábuas rijas e de prumos". (Re)construir e (re)habitar a casa-nação, por conseguinte, constitui o seu projeto - a tábua de salvação - de vida.

\section{O equilíbrio da concha}

O poema “Bairro negro”, de Glória de Sant’Anna (1961, p. 25-26), apresenta, nas três primeiras estrofes, a descrição das "pequenas casas maticadas/ [que] erguem-se de longe (de séculos, de antigas datas)/ contra o mar e as ondas e as algas" e de pronto estabelece um quadro opositivo entre o tempo e o espaço e entre a pequenez das "casas maticadas" e a imensidão do mar. No entanto, já nos previne o título que se trata de um "bairro" e, apesar de serem "maticadas" - "feitas com terra e cana" (SANTANNA, 1995) —, reunidas - tal feixes de cana -, essas casas adquirem força, erguendo-se "de longe (de séculos, de antigas datas)".

$\mathrm{Na}$ segunda estrofe, ao serem tomadas "Como remotas conchas embaciadas/ caídas de uma súbita maré alta (lúcida e predestinada)/ entre o areal e as ondulantes palmas", revela-se a metáfora da casaconcha que a partir de então permeia todo o poema. A concha, cuja simbologia costuma ser associada à fecundidade, em "Bairro negro" recebe um valor protetório tanto espacial quanto ontológico. Melhor explicando, ao serem também descritas como "cúbicas e caladas/ Onde os problemas são primários e as janelas fechadas", as casas sinalizam a idéia de estabilidade e de paraíso tão caras ao abrigo, à proteção; contudo, a quarta e a quinta estrofes constituem um enorme parêntese que desestabiliza o sujeito poético conforme nele insere algumas preocupações: "(Quem sofre dentro das rústicas portas não aplainadas?/ Ou se encosta chorando às trémulas arestas/ projectadas entre ângulos de acaso?// Que mar indeterminado e abstracto/ se reflecte num olhar ou num gesto marcado/ Por um ignoto hábito?)”.

Esse percurso interior parece conduzir para o que afirma Gaston Bachelard (2005, p. 123) quando trata da simbologia da concha: "ao 
conservar-se na imobilidade de sua concha, o ser prepara explosões temporais do ser, turbilhões do ser”. O traço existencial que costuma caracterizar a poética de Glória de Sant'Anna é confirmado na sexta e na sétima estrofes com a recuperação do título "Bairro negro" efetuada pelo sujeito poético quando proclama a igualdade entre as pessoas: "O céu é igual sobre cada telhado,/ o sol nasce o mesmo em todo o lugar/ e a lua é sempre dos poetas (fria e inacabada)". Podemos, assim, afirmar que a casa-concha, neste poema, guarda dois interiores: o do espaço externo em relação às casas e o do homem em relação a si mesmo, buscando a própria identidade.

\section{Algumas palavras mais...}

Como procuramos assinalar, as metáforas da casa aparecem com bastante freqüência e possuem conteúdo simbólico variado na poesia de Alda Lara, Conceição Lima e Glória de Sant'Anna. Abrigando ou desabrigando, a casa pode ser vista enquanto espaço físico, mas também como a representação do paraíso, do corpo, do cosmo, da memória, da solidariedade, da solidão, entre tantas outras.

A análise dos poemas nos mostra, ainda e principalmente, que, a par de todas essas metáforas da casa, a preocupação com a identidade constitui um dos traços mais marcantes na inscrição literária dessas três autoras africanas de língua portuguesa: Alda Lara demonstra predileção pelos espaços do interior ao criar sujeitos poéticos que indagam sobre o "estar" no mundo; Conceição Lima parece se voltar mais para ações concretas e, por isso, os sujeitos que permeiam sua poesia freqüentemente se preocupam com o "fazer" o mundo; por fim, Glória de Sant'Anna aparenta confirmar a voz da crítica ao apresentar uma poética existencial marcada, portanto, pelo interesse pelo "ser" do mundo.

Para finalizar, registramos que a preocupação com a questão da identidade não é uma exclusividade das autoras cujos poemas analisamos, constituindo um dos elementos norteadores das literaturas 
africanas de língua portuguesa. No entanto, no caso de Alda Lara, Conceição Lima e Glória de Sant'Anna, o interesse por tal insígnia se mostra de tal modo vinculado a suas poéticas que, nesse sentido, tomamos como imprescindivel a proclamação de suas singularidades.

\section{Referências bibliográficas}

ABDALA JUNIOR, Benjamin. Entre imagens da lua e do sol, a passagem: uma leitura antropológica de três poetas angolanas. In: De vôos e ilhas: literaturas e comunitarismos. São Paulo: Ateliê Editorial, 2003, p. 225237.

ADORNO, Theodor W. Notas de literatura I. Trad. Jorge M. B. de Almeida. São Paulo: Duas Cidades: 34, 2003.

ANTUNES, Érica. Uma leitura do conto "Fita Verde no Cabelo" de Guimarães Rosa. Revista Nave da Palavra. São José dos Campos, v. 86, 2002. Disponivel em: <http://www.navedapalavra.com.br/resenhas/1leituradocontofitaverde .htm>. Acesso em: 02 ago. 2002.

ARRIGUCCI JR., Davi. Humildade, paixão e morte: a poesia de Manuel Bandeira. 2. ed. São Paulo: Companhia das Letras, 2003, p. 64.

BACHELARD, Gaston. A poética do espaço. 1. ed., 7. tir. Trad. Antonio de Pádua Danesi. São Paulo: Martins Fontes, 2005.

BOSI, Alfredo. O ser e o tempo da poesia. 6. ed. São Paulo: Companhia das Letras, 2000.

ELIADE, Mircea. O sagrado e o profano: a essência das religiões. Trad. Rogério Fernandes. São Paulo: Martins Fontes, 2001, p. 144.

FRYE, Northrop. Fábulas de identidade: ensaios sobre mitopoética. Trad. Sandra Vasconcelos. São Paulo: Nova Alexandria, 2000.

LARA, Alda. Poemas. 4. ed. Porto: Vertente, 1984.

LIMA, Conceição. A dolorosa raiz do micondó. Lisboa: Editorial Caminho, 2006. O útero da casa. Lisboa: Editorial Caminho, 2004.

MARGARIDO, Alfredo. Estudos sobre literaturas das nações africanas de língua portuguesa. Lisboa: A Regra do Jogo, 1980.

MATA, Inocência. Apresentação. In: LIMA, Conceição. O útero da casa. Lisboa: Editorial Caminho, 2004, p. 11-15.

MEMMI, Albert. Retrato do colonizado precedido pelo retrato do colonizador. 3. ed. Trad. Roland Corbisier e Mariza Pinto Coelho. Rio de Janeiro: Paz e Terra, 1989.

ROSA, João Guimarães. Fita Verde no Cabelo: nova velha estória. 1. ed., 7. reimp. Rio de Janeiro: Nova Fronteira, 2004.

SANTANNA, Glória de. Algures no tempo. Ovar: Edição de Autor, 2005.

Livro de água. Lourenço Marques: Ed. de Autor, 1961.

Solamplo. Maputo: Ndjira, 2000.

Zum-zum. Lisboa: Edições Dinossauro, 1995.

SANTOS, Boaventura de Sousa. Pela mão de Alice: o social e o político na pósmodernidade. 9. ed. São Paulo: Cortez, 2003.

SECCO, Carmen Lucia Tindó. Uma poética de mar e silêncio... In: A magia das letras africanas: ensaios escolhidos sobre as literaturas de Angola, 
Moçambique e alguns outros diálogos. Rio de Janeiro: ABE Graph: Barroso Produções Editoriais, 2003.

SILVA, Manoel de Souza e. Do alheio ao próprio: a poesia em Moçambique. São Paulo: EDUSP; Goiânia: Editora da UFG, 1996. 